\title{
Assessing legal terminological variation in institutional translation
}

\author{
The case of national court names in the human \\ rights monitoring procedures of the United \\ Nations
}

\author{
Diego Guzmán and Fernando Prieto Ramos \\ University of Geneva
}

This paper presents the main findings of a study on the translation of national court names in United Nations texts as an illustrative group of culture-bound terms. It focuses on documents produced as part of several mandatory compliance monitoring procedures in the field of human rights. The study is part of a broader project on legal translation in international organisations (LETRINT), which considers terminological consistency and adequacy as indicators of translation quality, and examines the impact of legal asymmetry on both dimensions. To shed light on the first of these indicators, a comprehensive analysis of intertextual and intratextual variations of English-Spanish and French-Spanish translations of thirty terms was conducted. Over five thousand bi- and trilingual segments, extracted from three ad-hoc multilingual and parallel corpora, were examined. They cover the period between 2000 and 2017, and refer to six legal systems. At the intertextual level, the results corroborate that legal asymmetry has a significant impact on translation decision-making, while the assessment of intratextual variation points to a link between source text length, documental series and the degree of terminological consistency.

Keywords: legal translation, United Nations, culture-bound legal terms, national court names, terminological variation, consistency

\section{Introduction}

Legal terms, the main "prompts and points of access to knowledge structures of the domain" (Biel 2014, 43), constitute a central feature of legal translation. It is therefore unsurprising that a large proportion of the literature in Legal Transla- 
tion Studies has focused on the intricacies of the translation of legal terms, and more specifically of culture-bound terms. In the case of international legal texts, most of these studies examine law-making procedures, especially in the European Union (EU) institutions. However, law-making is just one of the several interrelated legal contexts of text production in international organisations. Despite the relevance of corpus-based research to better understand translation patterns in these contexts, product-oriented analyses of this kind are still quite rare in the case of the United Nations (UN). As in other international organisations, ensuring terminological consistency is essential at the UN, for the sake of legal univocity and certainty, and hence for translation quality assurance (Prieto Ramos 2014a, 314).

This paper includes a comprehensive assessment of intertextual and intratextual variations in the translation of the names of national courts (an example of legal culture-bound terms) that appear in texts submitted in the framework of UN procedures of human rights treaty compliance monitoring. These were chosen because of the significant share they represent in UN translation volumes and because they often include national legal terminology. As part of the terminological stream of a broader project on institutional translation, this study examines terminological decisions as a marker of methodological competence and quality in legal translation, in line with preliminary quantitative and qualitative analyses of the English-Spanish translation of procedural terminology (Prieto Ramos 2013, 2014b; Prieto Ramos and Guzmán 2018). The translation context under scrutiny will be presented in Section 2, including its main conditioning factors. The methodology, datasets and results will then be described in the second part (Sections 3 and 4 ).

\section{The translation of culture-bound legal terms in UN treaty body documents}

Our study focuses on key processes of monitoring of States' mandatory compliance with their obligations under international binding agreements on human rights: the examination of national reports in the framework of the Universal Periodic Review (UPR) and by the so-called 'treaty bodies', and individual complaints procedures before the latter.

The treaty bodies are a set of 10 committees created and mandated by virtue of the nine international core treaties on human rights adopted between 1965 and 2007. ${ }^{1}$ Due to their "[...] shared characteristics [...] in terms of their nature, func-

1. See updated list at: https://www.ohchr.org/EN/HRBodies/Pages/Overview.aspx. Accessed 18 August 2020. 
tions and powers, together with the steadily increasing, occasionally overlapping and sometimes contradictory demands placed on the States Parties", they have gradually been conceptualised as a system (Egan 2013, 211). During the consideration of national reports, both States and committees issue a number of texts that refer to national legal realities and must be translated into all official languages.

Established by the UN General Assembly in 2006 under Resolution 60/251, the UPR is a "peer review-based initiative" over the course of which a troika of States "[...] oversees the preparation and presentation of information regarding country adherence to a range of human rights criteria, and reports to the Human Rights Council (HRC) as a whole" (McMahon 2009, 356). Apart from the national report, the Office of the High Commissioner for Human Rights (OHCHR) prepares a compilation of UN information and a summary of stakeholders' information, while the working group in charge of the procedure issues a report on the outcome of the review, which leads to a decision by the HRC.

The mechanisms that deal with individual complaints on human rights violations can be described as semi-judicial, adversarial and confidential procedures, during which the burden of proof falls solely on the complainant (Vandenhole 2004, 286). Individuals from certain States can lodge communications alleging violations of their rights under the core treaties. When these communications are deemed admissible, committees issue documents, with titles like "communication", "decision", "views" or "opinion"; after considering the facts and the merits of the complaints, they sometimes recommend remedial actions.

Although not legally binding (Schmidt 2009, 25), the documents issued in all the above-mentioned procedures have legal significance and have been invoked by international jurisdictions (Rodley 2013, 641). They are translated to and from the six official UN languages by the staff of the Department for General Assembly and Conference Management at the United Nations Office at Geneva (UNOG), where the HRC and treaty bodies operate, and, to a lesser extent, at the Headquarters in New York. According to data collected as part of the LETRINT project, ${ }^{2}$ every year the UN Spanish translation services handle over seven thousand documents (forty-four million words). Around $90 \%$ of this workload is dealt with at UNOG and the Headquarters. Nine out of ten documents are originally drafted in English, thus confirming the prevalence of this language as a lingua franca at the UN (Cao and Zhao 2008; Prieto Ramos 2020). Translators deal with a wide range of subjects and textual genres. As a result, while legal translation "[...] is ubiquitous in UN translation work, it is hard to find a clear boundary between legal translation and non-legal translation" (Zhao and Cao 2013, 204). The results of LETRINT's full mapping of institutional texts from three years also corroborate the quantita-

2. See Prieto Ramos et al. (2019) for more information on the LINST corpus. 
tive and qualitative prominence of legal and administrative translation in a broad sense in this and other institutions (Prieto Ramos and Guzmán, 2021).

Under the UN's linguistic regime, documents published in any of its six official languages are equally authentic, unless otherwise specified. Translators are hence bound by Šarčević's $(1997,215-216)$ principle of "fidelity to the single" instrument and must "[...] strive for interlingual concordance". Authors like Nóbrega (2006) and Pérez-Barreiro Nolla (2005) have highlighted the importance of this requirement, especially when translating the results of negotiations. For the same reason, translators must carefully observe linguistic precedents (Sáenz Sagaseta de Ilúrdoz 1999; Zhao and Cao 2013), which requires them to conform to previous translations and recommendations in internal terminological resources, such as UNTERM. They must also follow the linguistic conventions characteristic of "UN style" (Nóbrega 2010). Finally, in the case of international languages like Spanish, which is official in many countries, translators are expected to observe a number of linguistic conventions aimed at striking a balance between the different variants of the target language, what has been described as "neutral" Spanish (Nóbrega 2006, 138). Its features are primarily tailored to the needs of the UN and other international organisations (e.g., García 2010, 398); more particularly, its search for neutrality has a direct impact on translation decision-making as it entails the pursuit of balance in reformulation, especially when dealing with singular national legal concepts.

Owing to their heightened conceptual incongruity or "systemic incompatibility" (Galdia 2017, 156), national culture-bound terms are frequently regarded as "untranslatable" (Šarčević 1997, 233). It is therefore unsurprising that the intricacies of their translation have been the subject of a steady flow of research. In the case of names of national judicial bodies in international settings, their translation has been addressed by several recent studies (see, for example, Millet 2013; Prieto Ramos 2013, 2014b; Peñaranda López 2015; Peruzzo 2019). They belong to one of the groups of terms that have been identified in international institutional settings as part of the LETRINT project (Prieto Ramos 2014b, 128-129): culture-bound terms designating legal specificities that must be conveyed in the target language in the selected genres mentioned above.

\section{Datasets and methodology}

\subsection{Corpora description}

All documents from the above procedures translated from English or French into Spanish between 2000 and 2017 were considered for the extraction of termi- 
nology. Two bilingual parallel and comparable subcorpora (English-Spanish and French-Spanish) were built with texts from an equal number of anglophone and francophone UN Member States (MS), with a view to ensuring the sufficiency and balance of our corpus in terms of language pairs and national legal systems. After an in-depth assessment of the participation of countries in the selected monitoring mechanisms, the following legal systems were chosen for examination: Australia (AUS), Belgium (BEL), Canada (CAN), England and Wales (EAW), ${ }^{3}$ France (FRA) and Switzerland (CHE). Their documents were downloaded from the HRC's "Documentation by country"4 repository and the UN Treaty Body Database $^{5}$ in accordance with the compilation criteria shown in Table 1.

During the data acquisition phase, we observed that a number of documents related to Canada were originally drafted in English or French, and in some cases both. Canadian texts were therefore included in the two initial subcorpora and in a third trilingual and parallel dataset (English/French-Spanish). This enabled us to compare the translations of the same legal concept from different source languages, and observe the potential impact of this double directionality on consistency.

Table 1. Selection criteria for corpora compilation

\begin{tabular}{|c|c|}
\hline Source language & Same than MS official language. \\
\hline Text availability & Source text and Spanish translation. \\
\hline Publication date & 01.01.2000-31.12.2017. Reference date: Spanish translation. \\
\hline Documental series & $\begin{array}{l}\text { All but "Information from Civil Society Organizations" }{ }^{*} \text { and HRC } \\
\text { decisions on the results of the UPR. }\end{array}$ \\
\hline
\end{tabular}

* These documents are not edited or translated by the UN's translation services.

Overall, 722 pairs of documents were downloaded, codified according to their metadata, converted to simple text formats and aligned into .tmx files. This was done using AlignFactory Light for the bilingual corpora and LF Aligner for the trilingual corpus. Before conducting any text queries, each alignment was individually reviewed and validated. The datasets sum up to 10.1 and 9.8 million tokens in the source languages and Spanish, respectively. In absolute terms, the Australian

3. Occurrences of Anglo-Welsh court names were extracted from documents related to the United Kingdom of Great Britain and Northern Ireland (GBR).

4. https://www.ohchr.org/EN/HRBodies/UPR/Pages/Documentation.aspx. Accessed 18 August 2020.

5. https://tbinternet.ohchr.org/_layouts/15/TreatyBodyExternal/countries.aspx. Accessed 18 August 2020. 
and the French Canadian subcorpora have the largest and smallest sizes, with 1.5 and 0.16 million tokens, respectively. ${ }^{6}$ However, if we add the Canadian documents included in the English-Spanish, the French-Spanish and the trilingual subcorpora, the total dataset of Canadian documents actually surpasses the Australian one, with 199 document pairs and 2.2 million tokens. The English-Spanish corpus (of 4.1 million tokens) is $54.93 \%$ larger than the French-Spanish one (2.6 million). This size difference reflects the weight of each official language in the UN.

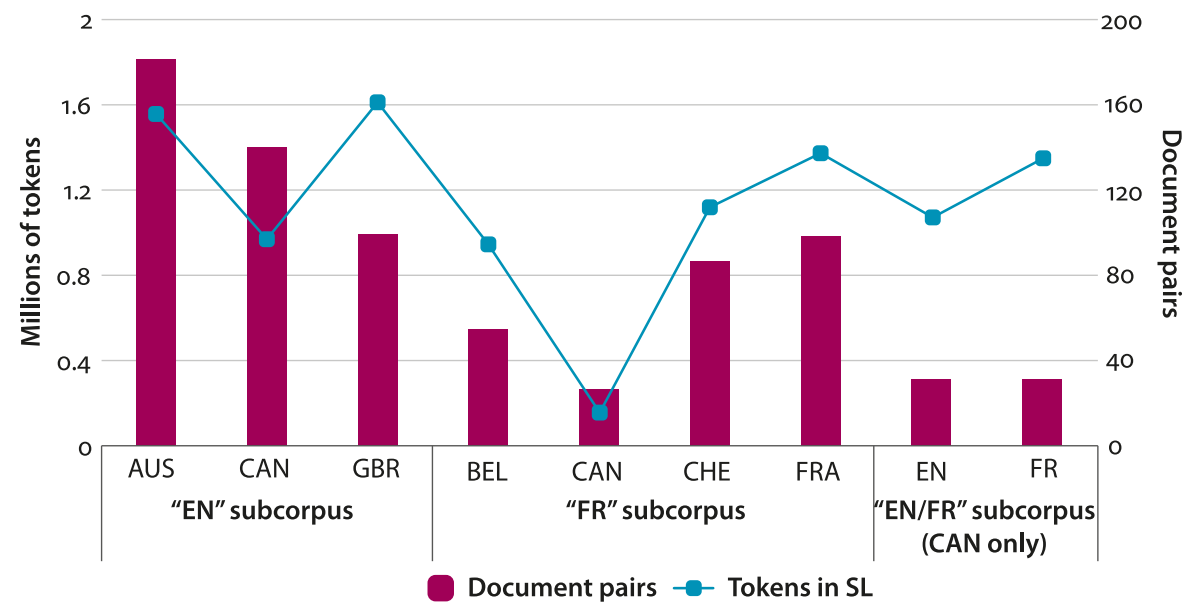

Figure 1. Distribution of corpora (source language word counts and document pairs)

The datasets contain 17,269 occurrences of the terms "court", "cour" and "tribunal". These were queried in the source texts using ApSIC Xbench 3.0 for the bilingual alignments and Agent Ransack for the trilingual alignments. Each entry was assigned an individual identification code based on its fifteen pieces of metadata. ${ }^{7}$ Slightly more than half of the segments were discarded for containing cases of ellipsis or generic uses of the queried terms $(45.46 \%)$, or terms relating to nonselected legal systems $(5.32 \%) .^{8}$ A further $6.72 \%$ of the entries were left out for including terms that had fewer than ten occurrences overall, or that referred to judicial bodies of secondary relevance to the study from a legal perspective (e.g.,

6. Unless otherwise stated, corpora word counts correspond to source languages only.

7. Source term, target term, judicial body, main source legal system (e.g., Australia), secondary source legal system (e.g., Western Australia), source corpus, source subcorpus, type of monitoring procedure (i.e., examination of national reports or individual complaints), monitoring mechanism (e.g., UPR or CAT), translation service (i.e., Geneva or New York), and source text identification code, documental series (e.g., report), issuer (i.e., MS or UN body) and language.

8. Terms designating supranational jurisdictions were also discarded. 
courts specialised in military or indigenous law, judicial bodies from British systems other than the Anglo-Welsh, or names of Swiss courts from non-Frenchspeaking cantons previously translated into French).

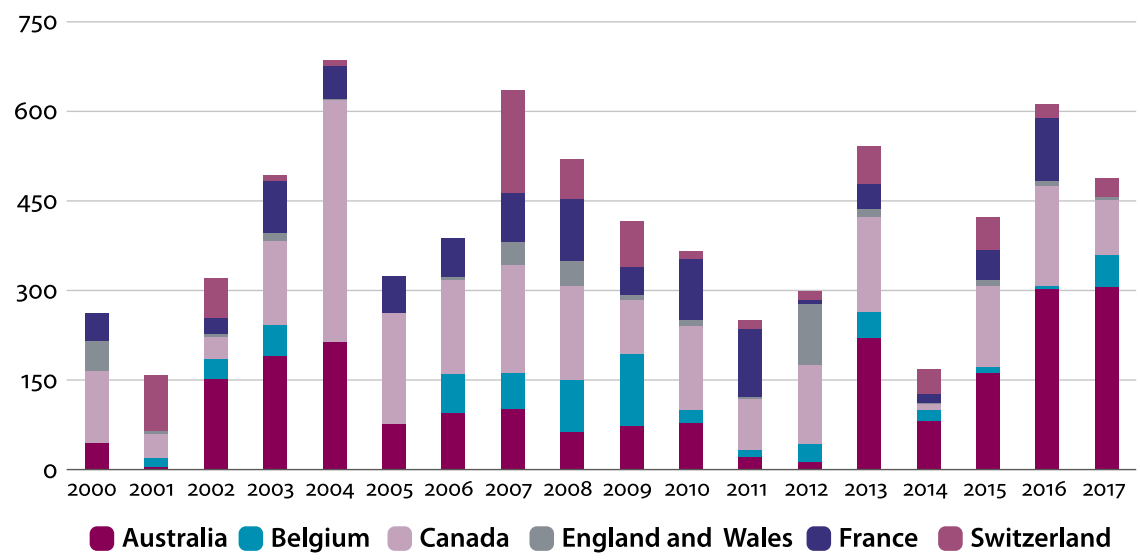

Figure 2. Distribution of occurrences considered for analysis by year and source legal system

Among the remaining 7,339 segments (hereafter referred to as eligible occurrences [EO]), 57 source terms (STs) were identified, designating courts from the six selected legal systems. They constitute a very heterogenous set of bodies. Not only are they found at both the top and the bottom of their respective judicial systems (e.g., the "Cour de cassation" and the "Tribunal de première instance" in Belgium) but their areas of competence range from criminal and family law to much more specialised branches (e.g., the Australian family and magistrates courts, or the Refugee Review Tribunal). The Australian, Canadian and Swiss datasets contain references to courts of both federal and state/territory/canton jurisdictions (e.g., the Canadian Federal Court and the Albertan Court of Queen's Bench).

The analysis focuses on a sample of STs selected according to three quantitative and three qualitative criteria. From a quantitative perspective, the selection included a minimum of three and a maximum of six terms per legal system. Secondly, to ensure representativeness, each national sample would have to gather more than $50 \%$ of the EO. Thirdly, a minimum of three terms were chosen amongst the top five most frequently found STs. The remaining STs were selected according to the following qualitative criteria, with a view to enriching the comparative nature of our assessment:

1. STs designating homonymous courts in two or more of the selected legal systems (e.g., "Tribunal correctionnel" in France and Belgium); 
2. STs corresponding to different titles held by the same judicial body over the course of the period of study as a result of a reform (i.e., the pairs "Federal Circuit Court" / "Federal Magistrates Court" and "Cour d'arbitrage" / "Cour constitutionnelle" in Australia and Belgium, respectively);

3. STs relating to judicial bodies with shared features and competences in several regional jurisdictions (i.e., the intermediate appellate courts of the Canadian provinces and territories).

Table 2. Terms selected for assessment

\begin{tabular}{|c|c|c|c|}
\hline & Sel. criteria & Term & Occurrences \\
\hline \multirow{6}{*}{ AUS } & \multirow{3}{*}{ quantitative } & High Court & \multirow{6}{*}{$\begin{array}{c}1,532 \\
(68 \% \text { of EO) }\end{array}$} \\
\hline & & Federal Court & \\
\hline & & Supreme Court & \\
\hline & \multirow{3}{*}{ qualitative } & Federal Magistrates Court & \\
\hline & & Federal Circuit Court & \\
\hline & & Magistrates Court & \\
\hline \multirow{6}{*}{ BEL } & & Cour d'appel & \multirow{6}{*}{$\begin{array}{c}376 \\
(66.31 \% \text { of } E O)\end{array}$} \\
\hline & quantitative & Cour de cassation & \\
\hline & & Tribunal correctionnel & \\
\hline & \multirow{3}{*}{ qualitative } & Cour d'arbitrage & \\
\hline & & Cour constitutionnelle & \\
\hline & & Cour d'assises & \\
\hline \multirow{12}{*}{ CAN } & \multirow{6}{*}{ quantitative } & Federal Court & \multirow{12}{*}{$\begin{array}{c}2,019 \\
(82.78 \% \text { of } E O)\end{array}$} \\
\hline & & Cour fédérale & \\
\hline & & Supreme Court of Canada & \\
\hline & & Cour suprême du Canada & \\
\hline & & Court of Appeal & \\
\hline & & Cour d'appel & \\
\hline & \multirow{6}{*}{ qualitative } & Superior Court & \\
\hline & & Cour supérieure & \\
\hline & & Supreme Court & \\
\hline & & Cour suprême & \\
\hline & & Court of Queen's Bench & \\
\hline & & Cour du Banc de la Reine & \\
\hline
\end{tabular}


Table 2. (continued)

\begin{tabular}{|c|c|c|c|}
\hline & Sel. criteria & Term & Occurrences \\
\hline \multirow{4}{*}{ EAW } & \multirow{4}{*}{ quantitative } & High Court & \multirow{4}{*}{$\begin{array}{c}259 \\
(80 \% \text { of EO) }\end{array}$} \\
\hline & & Crown Court & \\
\hline & & Magistrates' Court & \\
\hline & & Court of Appeal & \\
\hline \multirow{5}{*}{ FRA } & \multirow{4}{*}{ quantitative } & Cour de cassation & \multirow{5}{*}{$\begin{array}{c}774 \\
(77.40 \% \text { of EO) }\end{array}$} \\
\hline & & Cour d'appel & \\
\hline & & Tribunal correctionnel & \\
\hline & & Tribunal de grande instance & \\
\hline & qualitative & Cour d'assises & \\
\hline \multirow{4}{*}{ CHE } & \multirow{3}{*}{ quantitative } & Tribunal fédéral & \multirow{3}{*}{$\begin{array}{c}597 \\
(79.28 \% \text { of EO) }\end{array}$} \\
\hline & & Tribunal pénal fédéral & \\
\hline & & Tribunal cantonal & \\
\hline & \multicolumn{2}{|r|}{ Total } & $\begin{array}{c}5,557 \\
(75.72 \% \text { of EO) }\end{array}$ \\
\hline
\end{tabular}

The sampling led to the selection of 30 terms designating 28 courts, as specified in Table 2. Their occurrences are distributed across 491 pairs of documents (i.e., $68 \%$ of the compiled datasets).

\subsection{Variation as an indicator of consistency}

For the purpose of the analysis, intertextual variation is understood as the use of two or more renderings of the same linguistic unit in multiple target texts. As with other objects of study, intertextual variation can be examined from multiple perspectives in light of varying translation briefs. In our case, a shared translation brief constitutes a fundamental condition to analyse terminological harmonisation and consistency as a priority in a given international institutional setting. As a general rule, low variation is associated to high consistency. Because of the very nature of court names, this consistency must be preserved in order to promote semantic accuracy and avert confusion across texts.

The degree of intertextual variation is linked both to the number of translation solutions and to their weight in the distribution of target segments. For example, in a situation where a particular term occurs in 600 segments and is translated in three different ways, is the degree of variation the same: (a) if these solutions have an equal frequency (200-200-200), and (b) if one of them is considerably 
more recurrent (e.g., 570-20-10)? The potential role of target term (TT) distribution as a mitigating or aggravating condition is computed through factor $\lambda$, which increases as the TT frequency diminishes. The resulting intertextual variation rate (InterVaR) is equal to the sum of each TT frequency multiplied by their respective $\lambda$ factor, divided by the ST total frequency. If the InterVaR equals one point, then no intertextual variation occurs. By contrast, an increase in the resulting value indicates a higher degree of inconsistency.

Table 3. Intertextual variation rate (InterVaR)

\begin{tabular}{lcc}
\hline & Occurrences & Factor $\lambda$ \\
\hline Solution Z & $\alpha(\ldots>\alpha)$ & $v(\ldots+1)$ \\
$\ldots$ & $\ldots$ & $\ldots$ \\
Solution B & $\chi(\psi>\chi)$ & $2(\mathrm{i}+1)$ \\
Solution A & $\psi$ & $1(\mathrm{i})$ \\
Total & $\omega\left(\sum_{-} \psi^{\wedge} \alpha\right)$ & \\
InterVaR & $\frac{\sum_{\mathrm{i}=\alpha}^{\psi} \delta \mathrm{i}}{\omega}$ & \\
\hline
\end{tabular}

At the intratextual level, variation is understood as the use of two or more renderings of the same linguistic unit in a single target text. The degree of consistency is thus determined by two factors: the frequency of the ST in the source text and the number of TTs found in the target text. With regard to the latter, as with intertextual variation, unless otherwise justified, heterogeneity in the target text equates to reduced consistency. In the calculation of the intratextual variation rate (IntraVaR), this is accommodated using factor $\kappa$, which is equal to the number of TTs found in the target text. The former component assumes that a higher frequency of the ST in the source text increases the likelihood of observing intratextual variation in the target text. This is signified through factor $\rho$, which rises with lower frequencies of the ST. To calculate the IntraVaR, source texts are categorised according to the ST frequency and the number of TTs in their corresponding target texts. The totals for each group are multiplied by their corresponding $\kappa$ and $\rho$ factors and added up. The IntraVaR equals the quotient of this sum divided by the total amount of source texts containing the ST. If no intratextual variation occurs, then the IntraVaR will equal one point. By contrast, the higher the value, the more heterogeneity.

In all cases, we did not consider spelling differences (e.g., inconsistent use of capitals) or number inflection as cases of variation. Instances where the ST was omitted in the target segment or when the segment as a whole remained untrans- 
Table 4. Intratextual variation rate (IntraVaR)

\begin{tabular}{llcccc}
\hline & \multicolumn{4}{c}{ TTs per document (factor $\kappa)$} & \\
\cline { 2 - 5 } Documents by ST frequency & $\mathbf{1}$ & $\mathbf{2}$ & $\mathbf{3}$ & Factor $\rho$ \\
\hline+10 occurrences & $\alpha$ & $\varepsilon$ & $\theta$ & $\ldots$ & 1 \\
6-10 occurrences & $\beta$ & $\zeta$ & $\ldots$ & $\ldots$ & 2 \\
2-5 occurrences & $\gamma$ & $\eta$ & $\ldots$ & $\pi$ & 3 \\
One occurrence & $\delta$ & $\delta$ & & NA & \\
Total & $\omega\left(\Sigma_{-} \alpha^{\wedge} \delta\right)$ & & & \\
IntraVaR & $\frac{\varepsilon+\zeta+\eta+\Sigma_{\pi}^{\theta} \kappa \rho}{(\omega-\delta)}$ & & & \\
\hline
\end{tabular}

lated (e.g., bibliographical references) were also excluded from the analyses. As a result, $1.15 \%$ of the occurrences containing the selected STs were discarded from the assessment.

\section{Results}

In this section we will outline the findings of our intertextual and intratextual variation analyses, with a particular emphasis on the potential impact of source language, ST frequency, legal asymmetry and source text length on these indicators. To further illustrate the general trends observed, we will then concentrate on four selected STs.

\subsection{Overview of variation rates}

The selected STs record a mean InterVaR-IntraVaR bracket of 1.41-1.73 points, with average brackets of 1.29-1.55, 1.40-1.74 and 1.16-1.16 for STs translated from English ("EN"), French ("FR") and in bilingual documents ("EN/FR"), respectively. Full consistency is observed in the translations of the following terms, which account for $13.73 \%$ of the analysed occurrences: "Supreme Court of Canada", "Federal Court" / "Cour fédérale" (CAN; only when translated in bilingual documents), "Superior Court" / "Cour supérieure" (CAN), "Cour de cassation" (BEL), "Cour d’arbitrage" (BEL), "Tribunal pénal fédéral” (CHE) and "Tribunal fédéral" (CHE). The remaining STs can be categorised into five groups according to their consistency levels:

a. high (1.01-1.01 to $1.25-1.25)$; 
b. medium (1.26-1.26 to $1.75-1.75)$;

c. low (1.76-1.76 or higher);

d. high intertextual variability (InterVaR $\geq 1.26$; IntraVaR $=1-1.25$ );

e. high intratextual variability (InterVaR=1-1.25; IntraVaR $\geq 1.26$ ).

Slightly more than one quarter of STs $(26.67 \%)$ fall into the high consistency bracket, one third show medium (10\%) or high $(23.33 \%)$ variation levels, and $23.34 \%$ of terms hit higher variation values only at the intertextual or intratextual level (with the other indicator under 1.25 points). The median variability bracket stands at 1.26-1.52 points. Although we observe a more or less evenly distribution of terms above and below the median bracket values (13 and 17 terms, respectively), STs with a lower degree of variability amount to a much larger share of occurrences.

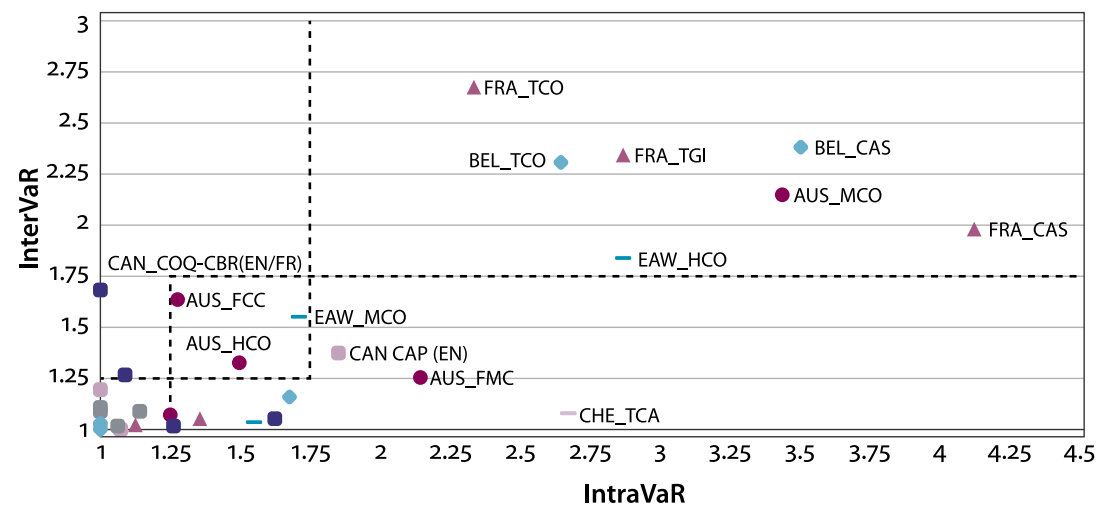

AUS - EAW CAN (EN) $O$ CAN (EN/FR) OCAN (FR) $\triangle$ FRA BEL - CHE

Legend (from left to right): CAN_CQB/CBR (EN/FR): "Court of Queen's Bench" / "Cour du Banc de la Reine" (when translated in bilingual documents); AUS_FCC: "Federal Circuit Court" (AUS); AUS_HCO: "High Court" (AUS); EAW_MCO: "Magistrates Court" (EAW); CAN_CAP: "Court of Appeal" / "Cour d'appel" (CAN); AUS_FMC: "Federal Magistrates Court" (AUS); FRA_TCO: "Tribunal correctionnel" (FRA); BEL_TCO: "Tribunal correctionnel" (BEL); CHE_TCA: "Tribunal cantonal" (CHE); FRA_TGI: "Tribunal de grande instance" (FRA); EAW_HCO: "High Court" (EAW); AUS_MCO: “Magistrates' Court” (AUS); BEL_CAS: “Cour d'assises” (BEL); FRA_CAS: "Cour d'assises" (FRA).

Figure 3. STs distribution by variation rates

As evidenced by Table 5, the number of English STs showing full consistency or lower levels of variability is almost identical to that of French STs. Terms translated in bilingual documents show a stronger tendency to consistency (two thirds of them attain [almost] full homogeneity), although the size of the subset is comparatively limited to draw conclusions from this finding. However, based on the overall results per language pair, we can infer that no significant differences in 
translation variability exist between English-Spanish and French-Spanish translations.

Recurrence differs substantially between STs. The results of a comparison of trends by frequency quintiles point to higher variation levels among terms of quintiles 3 and 5, with more moderate values in the case of quintiles 1, 2 and 4 (see Figure 4). Although the upward trend is not continuous, it suggests that, at higher prevalence, terms are translated more consistently. However, a closer look at the composition of the quintiles reveals that lower frequency groups (namely, quintiles 3 and 5) consist of larger shares of terms that designate judicial bodies operating either in the lowest echelons of their justice systems (e.g., "Magistrates Court" in quintiles 3 [EAW] and 4 [AUS]), in specific geographic jurisdictions (e.g., "Court of Queen's Bench" / "Cour du Banc de la Reine" [CAN] in quintile 5) or under special circumstances (e.g., "Cour d'assises" [FRA and BEL] in quintile 5). This probably accounts for their lower frequency in the corpus documents.

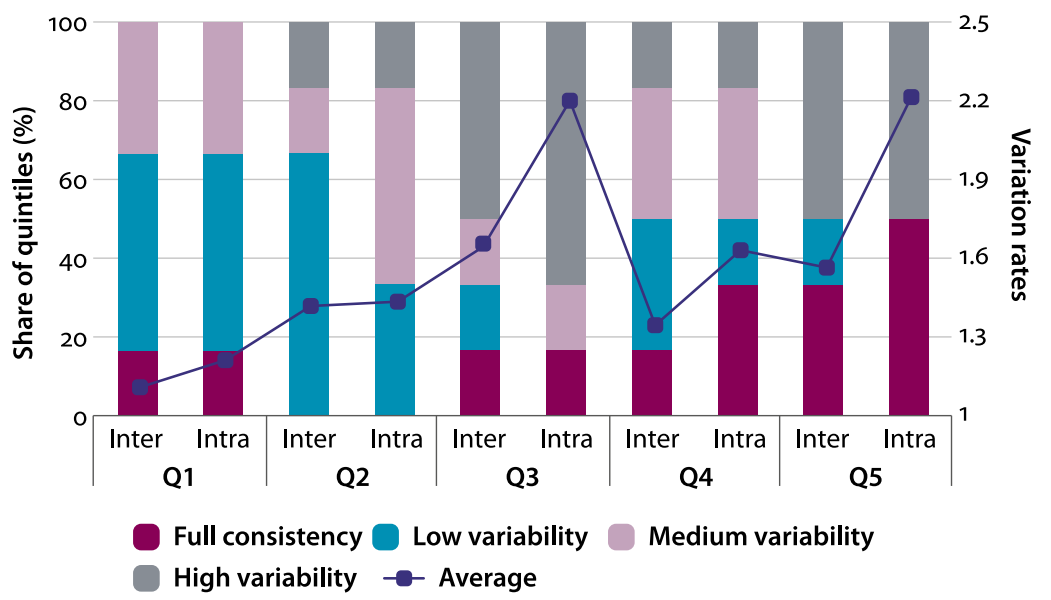

Figure 4. STs distribution by frequency quintiles and variability brackets, and average variation rates per quintile ${ }^{9}$

By contrast, quintiles 1 and 2 mostly consist of top-tier and general courts like the Australian and Canadian national and territorial supreme and federal courts, and the French and Canadian appeal courts or "cours d'appel". Apart from their higher recurrence, the denominations of these judicial bodies can be considered less legally singular, and generally more "transparent" and less prone to incongruity in legal translation. This would suggest that the increase in variability is

9. The first quintile (Q1) gathers the more frequent STs, whereas the last one (Q5) includes less recurrent STs. For Canadian STs, the overall results of the assessment are considered. 


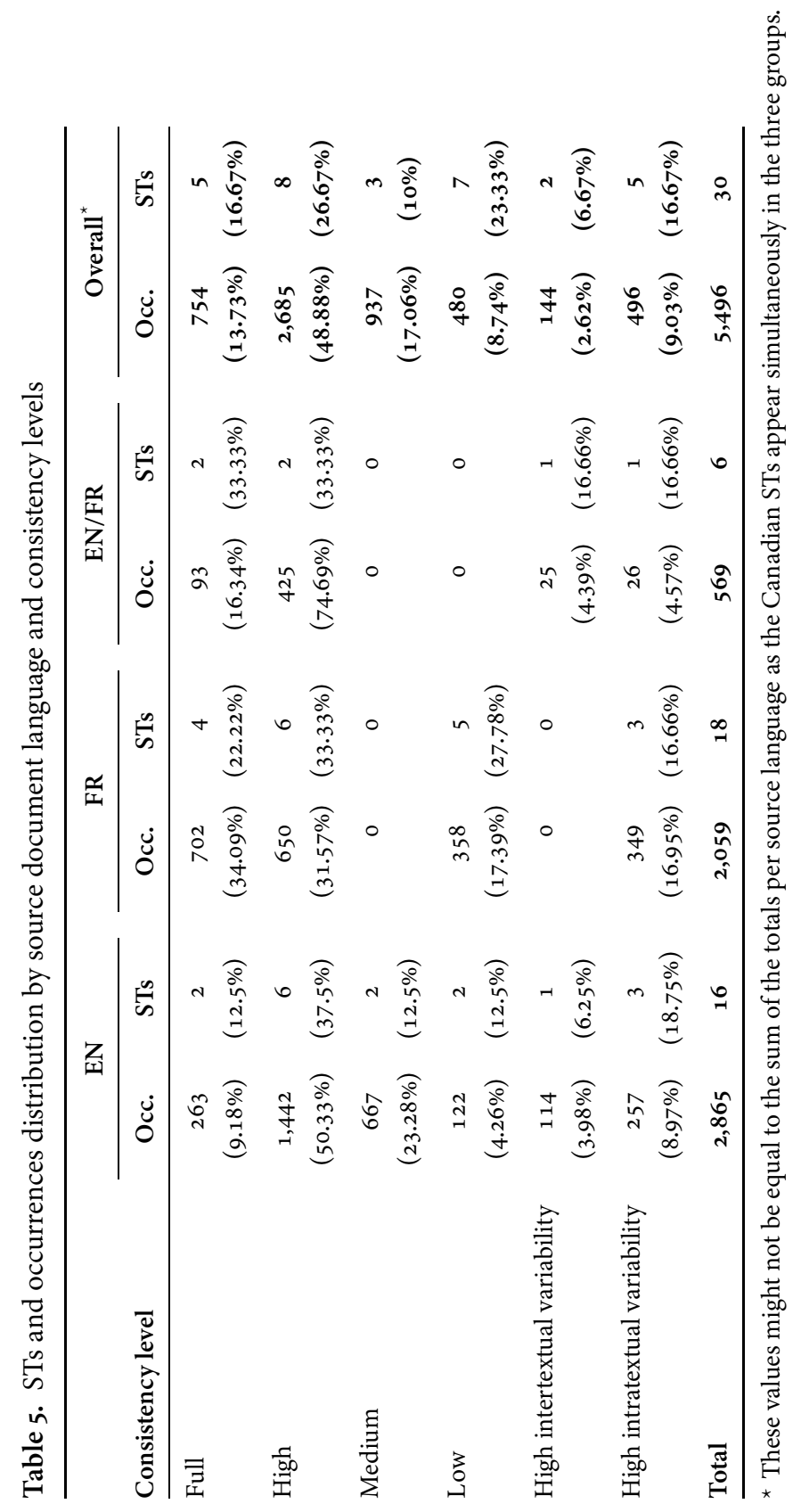


linked to the characteristics of the legal terms, rather than to their frequency in a given translation context.

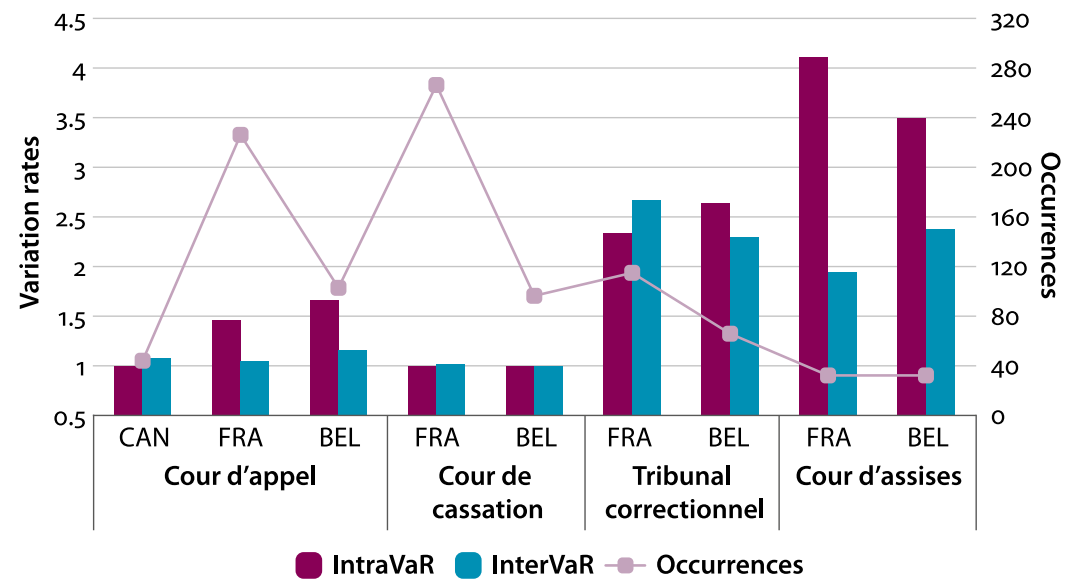

Figure 5. Frequencies and variation rates of homonymous terms (French STs)

A comparison of the translation variation rates of homonymous judicial bodies supports the same conclusion. As shown in Figure 5, regardless of the source legal system, the InterVaR and IntraVaR of the terms "Tribunal correctionnel" and "Cour d'assises" exceed 1.95 points in all cases. Conversely, with the exception of the IntraVaR values for the French and Belgian "Cour d'appel" (1.45 and 1.66 points, respectively), the translation of the terms "Cour d'appel" and "Cour de cassation" is fully consistent. Despite an almost identical frequency, "Cour d'assises" variation values double or triple those observed for "Court of Appeal" / "Cour d'appel" (CAN). The same applies to the terms "Tribunal correctionnel" (FRA) and "Cour d'appel' (BEL).

A similar comparison between STs translated from English reveals analogous results. While the terms "Supreme Court" and "Federal Court" systematically hit extremely low variability rates, both at the intertextual and the intratextual levels, the translation of "Magistrates Court" exceeds 1.5 points. Only the InterVar of the partially related term "Federal Magistrates Court" (AUS, 1.25) is below that value. Nevertheless, this term, in common with "Magistrates Court" (AUS and EAW), has a higher frequency than "Supreme Court" (CAN), which also suggests that frequency is not an aggravating factor of variability. It would appear that terms that refer to more singular concepts from a legal comparative perspective (e.g., assises in "Cour d'assises") record higher degrees of translation variation.

Apart from terms showing full translation consistency at the intertextual level (which excludes any likelihood of intratextual inconsistency), all but two terms 
("Cour constitutionnelle" [BEL] and "Court of Queen's Bench" / "Cour du Banc de la Reine" [CAN]) exhibit varying degrees of intratextual variation in their translations. Within this group, "Federal Court" (AUS) has the lowest IntraVaR (1.06 points), while "Cour d'assises" (FRA) hits the highest value (4.11 points), followed by its Belgian equivalent (3.5 points).

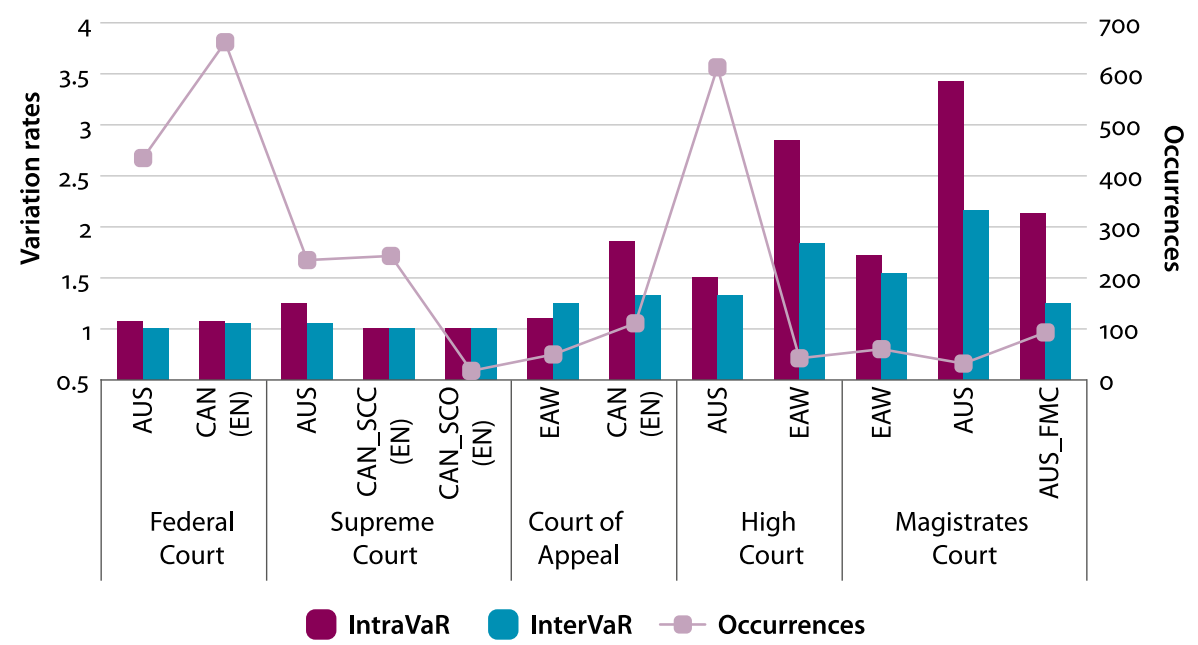

Figure 6. Frequencies and variation rates of homonymous terms (English STs)

These patterns do not uniformly affect documental series. Intratextual variation was found in 76 of the 491 pairs of documents $(15.47 \%)$ containing occurrences of the analysed terms. Almost half of them $(43.42 \%)$ are national reports submitted to the treaty bodies or as part of the UPR; $38.16 \%$ were produced in individual complaints procedures; and $15.78 \%$ are MS replies to the committees' lists of issues. One summary record and a follow-up report (2.64\%) complete the list. In $88.15 \%$ of these documents, the STs affected by intratextual variation have been translated in two different ways. Only five national reports and four replies to lists of issues include three or four solutions per ST. In proportional terms, the share of affected texts varies considerably across the above-mentioned document types. Intratextual variation occurs in half of the replies to lists of issues, while $27.5 \%$ of national reports and $12.39 \%$ of individual complaint documents are affected. The latter is, however, the most prevalent documental series containing STs $(47.65 \%)$, followed by national reports $(24.41 \%)$, replies to lists of issues (7.33\%) and summary records (7.13\%). Despite the similar frequencies of the last two groups, intratextual variation is much more recurrent in lists of issues than in summary records. 


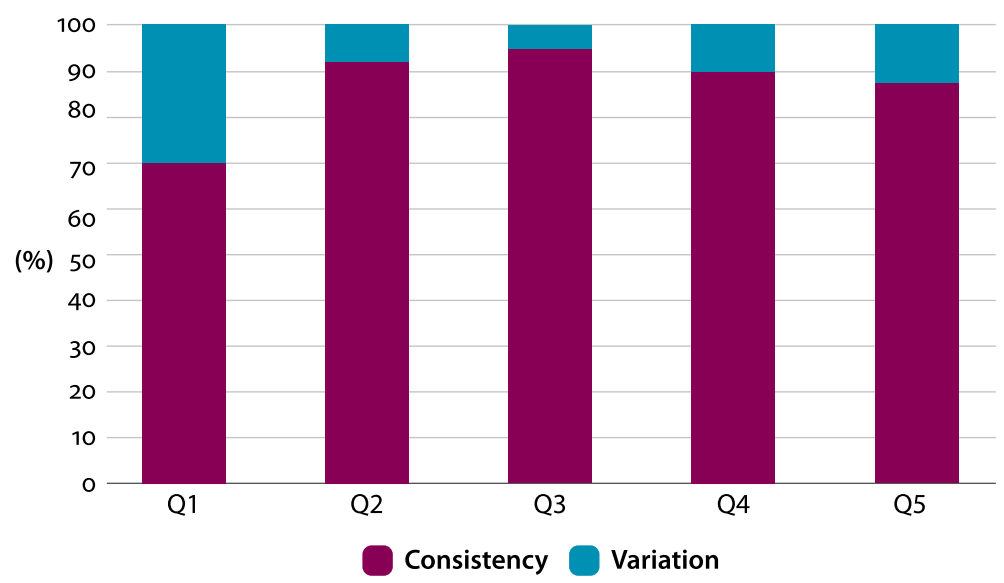

Figure 7. Distribution of intratextual variation in source texts by length quintiles (only documents including analysed STs $)^{10}$

Our findings suggest that intratextual variation values cannot be correlated to the recurrence of translations in specific documental series. However, they reveal the potential impact of varying levels of quality control per documental series, as the higher IntraVaR found in the replies to lists of issues contrasts with the most consistent patterns in individual complaint documents in particular. The findings also point to another potential aggravating factor: the size of the source text. With an average of 37,619 words per source document, national reports are by far the lengthiest documents, followed by replies from MS to lists of issues (19,328 words per document). Individual complaint documents are generally much shorter, at an average of 6,329 words per document. If we classify the length of all documents affected by intratextual variation (see Figure 7), we observe that $30 \%$ of length quintile 1 (most sizeable documents) contain instances of intratextual variation. Although all groups are affected, on average, this type of variation was found in $9.14 \%$ of the documents of the remaining quintiles, with the highest share in quintile $5(12.63 \%)$. Hence, the gap is significant enough to suggest that the length of the source document increases the risk of intratextual variability.

\subsection{Translation variability of illustrative terms}

The findings for the terms "Tribunal correctionnel" (BEL), "Magistrates' Court" (AUS), "Supreme Court of Canada" / "Cour suprême du Canada" (CAN) and "Tribunal fédéral" (CHE) serve to further illustrate the above-mentioned patterns

10. The first quintile (Q1) includes the longest texts. Shorter source texts are grouped under the last quintile (Q5). 
and to examine the potential connection between translation variation and legal asymmetry in particular. In practice, the Belgian Tribunal correctionnel is the criminal division of the Tribunal de premiere instance. Under article 92 of the Code judiciaire, it has original jurisdiction on misdemeanours that are subject to over seven days' imprisonment (or fines greater than 0.62 euros), and can hear appeals against judgments of the Tribunal de police. No exact functional or conceptual correspondence for this term can be found in Spanish-speaking jurisdictions. Something similar occurs in the case of the second illustrative term, “Magistrates' Court”. In the Australian Capital Territory, Queensland, South Australia, Tasmania and Victoria, criminal and civil cases triable by summary procedure (i.e., as a result of minor offences or small claims) are heard by a judge or multiple lay magistrates in this type of court.

Conversely, the concepts behind the last two terms are easy to recognize by Spanish readers: the Supreme Court of Canada / Cour suprême du Canada and the Tribunal fédéral occupy the highest ranks of the Canadian and Swiss judicial systems, respectively. These courts hear appeals of last resort from federal and territorial, state or cantonal bodies, with a view to ensuring the uniform application of the law.

Table 6. Translation variability indicators for selected STs

\begin{tabular}{llcccc}
\hline Term & & Translations & Occurrences & InterVaR & IntraVaR \\
\hline Magistrates' Court (AUS) & & 9 & 33 & 2.15 & 3.43 \\
\hline Tribunal correctionnel (BEL) & & 7 & 65 & 2.29 & 2.64 \\
\hline Supreme Court of Canada & Overall & 3 & 607 & 1.01 & 1.1 \\
Cour suprême du Canada & EN & 1 & 243 & 1.00 & 1.00 \\
& FR & 3 & 55 & 1.07 & 1.14 \\
& EN/FR & 2 & 309 & 1.01 & 1.26 \\
\hline Tribunal fédéral (CHE) & & 1 & 558 & 1.00 & 1.00 \\
\hline
\end{tabular}

According to our datasets, the translations of these four STs follow very different trends. "Magistrates' Court" (AUS) and "Tribunal correctionnel" (BEL) have been translated in nine and seven different ways and reach InterVaR values of 2.15 and 2.29 points, respectively. By contrast, the renderings of "Tribunal fédéral" (CHE) and "Supreme Court of Canada" attain full or very high consistency in Spanish. Regarding the latter term, while three and two solutions have been identified among segments extracted from French and bilingual documents, the high incidence of the predominant solutions ( $94.5 \%$ and $99.03 \%$, respectively) imply very low InterVaRs (1.07 and 1.01, respectively). The three solutions observed for this ST match the (conceptually "transparent") denominations of top-tier courts 
in highly populated Spanish-speaking countries like Mexico ("Tribunal Superior"), Spain ("Tribunal Supremo") and Argentina ("Corte Suprema"). The reformulation used in the case of "Tribunal fédéral" ("Tribunal Federal") does not designate any jurisdiction in these countries. However, the key concept of federal can also be easily identified and entails no risk of conceptual misinterpretation among target readers.

Only two of the seven TTs identified in the assessment of "Tribunal correctionnel" (BEL), accounting for $38.46 \%$ of its occurrences, can be categorised as literal translations ("Tribunal Correccional" and "Tribunal correccional de primera instancia"). Contrary to the reformulations used for "Supreme Court of Canada" / "Cour supreme du Canada", "tribunal correccional" is not a widespread designation of criminal trial bodies in Spanish-speaking countries. This term only identifies the criminal divisions of Peruvian appellate courts (Cortes Superiores). Both the heterogeneity of the target audience in this context, and the divergent natures of the Belgian Tribunal correctionnel and the Peruvian Tribunal correccional, reduce the acceptability of this rendering in Spanish. Finally, literal translations account for two of the nine reformulations (9.09\% of occurrences) retrieved for "Magistrates' Court" (AUS). However, not only is the term "Tribunal de Magistrados" extraneous among Spanish-speaking judicial systems, but the use of magistrados (supreme court judges in Spanish-speaking judiciaries) as a translation of "magistrates" constitutes a "false friend" (see, e.g., Prieto Ramos 2013).

Table 7. Examples of intratextual variation in the translation of the terms "Magistrates' Court" (AUS) and "Tribunal correctionnel" (BEL)

\begin{tabular}{|c|c|c|c|}
\hline Document & Occurrence & Source segment & Target segment \\
\hline 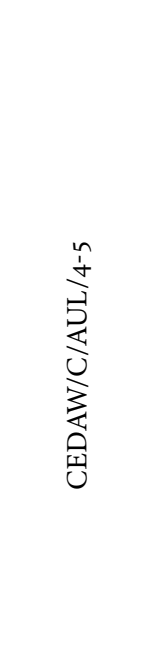 & $\begin{array}{l}\mathrm{AU} / \mathrm{MaC} / \\
\text { 04/004 }\end{array}$ & $\begin{array}{l}\text { It administers the Brisbane } \\
\text { Court Assistance programme } \\
\text { operating in the Brisbane } \\
\text { Magistrates Court and is also } \\
\text { responsible for the } \\
\text { development, implementation } \\
\text { and evaluation of the Violence } \\
\text { Against Women Strategy. } \\
\text { The Northern Violence } \\
\text { Intervention Programme has } \\
\text { been developed to respond to } \\
\text { the needs of families affected by } \\
\text { domestic violence in the area } \\
\text { covered by the Elizabeth } \\
\text { Magistrates Court. }\end{array}$ & $\begin{array}{l}\text { Administra el programa de } \\
\text { Asistencia del Juzgado de Brisbane } \\
\text { que funciona en el Juzgado de menor } \\
\text { cuantía de Brisbane y es responsable } \\
\text { de la elaboración, aplicación y } \\
\text { evaluación de la Estrategia sobre la } \\
\text { violencia contra la mujer. } \\
\text { El Programa septentrional de } \\
\text { intervención en casos de violencia } \\
\text { ha sido elaborado para responder a } \\
\text { las necesidades de las familias } \\
\text { afectadas por la violencia en el hogar } \\
\text { dentro de la jurisdicción del tribunal } \\
\text { de menor cuantía de Elizabeth. }\end{array}$ \\
\hline
\end{tabular}




\begin{tabular}{|c|c|c|c|}
\hline Document & Occurrence & Source segment & Target segment \\
\hline \multirow{15}{*}{ 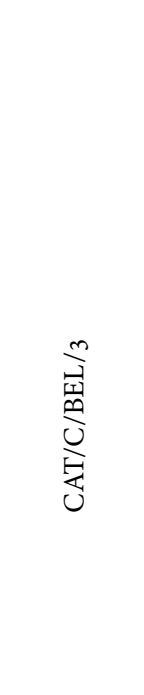 } & \multirow{11}{*}{$\begin{array}{l}\mathrm{BE} / \mathrm{TCo} / \\
12 / \mathrm{oo} 1\end{array}$} & Si le ministère public décide de & \multirow{11}{*}{$\begin{array}{l}\text { Si el Ministerio Fiscal decide } \\
\text { enjuiciar el menor tras la inhibición, } \\
\text { en principio este será juzgado por } \\
\text { una sala específica del Tribunal de } \\
\text { Menores, integrada por tres jueces, } \\
\text { dos de los cuales habrán recibido la } \\
\text { formación necesaria para el ejercicio } \\
\text { de la función de juez de menores, } \\
\text { mientras que el tercero será un juez } \\
\text { del tribunal correccional. }\end{array}$} \\
\hline & & poursuivre le jeune après & \\
\hline & & dessaisissement, il sera en & \\
\hline & & principe jugé par une chambre & \\
\hline & & spécifique du tribunal de la & \\
\hline & & jeunesse composée de trois & \\
\hline & & juges, dont deux ont suivi la & \\
\hline & & formation requise pour & \\
\hline & & l'exercice de la fonction de juge & \\
\hline & & de la jeunesse, le troisième étant & \\
\hline & & $\begin{array}{l}\text { un juge du tribunal } \\
\text { correctionnel. }\end{array}$ & \\
\hline & \multirow{4}{*}{$\begin{array}{l}\mathrm{BE} / \mathrm{TCo} / \\
12 / 005\end{array}$} & \multirow{4}{*}{$\begin{array}{l}\text { Par décision du tribunal } \\
\text { correctionnel d’Anvers, un } \\
\text { enseignant a été puni pour avoir } \\
\text { utilisé des châtiments corporels. }\end{array}$} & En un fallo del Tribunal Penal de \\
\hline & & & Amberes, se condenó a un docente \\
\hline & & & por haber utilizado castigos \\
\hline & & & corporales. \\
\hline
\end{tabular}

If we focus on their IntraVaR results, the terms "Magistrates' Court" (AUS) (with 3.43 points) and "Tribunal correctionnel" (BEL) (2.64) also show high levels of intratextual variability. In most cases, this occurs in national reports submitted to the treaty bodies. For instance, occurrences $\mathrm{AU} / \mathrm{MaC} / \mathrm{O} 4 / \mathrm{oo}$ and $\mathrm{AU} / \mathrm{MaC} / \mathrm{O} 4 /$ 004 were detected in the combined fourth and fifth periodic reports submitted by Australia to the CEDAW in 2004, while segments $\mathrm{BE} / \mathrm{TCo} / 12 / 001$ and $\mathrm{BE} /$ $\mathrm{TCo} / 12 / 005$ are part of the third periodic report presented by Belgium to the CAT in 2012 (see Table 7). Of the nine documents where intratextual variation was identified for these two STs and "Supreme Court of Canada" / "Cour suprême $d u$ Canada", four are national reports and three are replies of the MS to the lists of issues produced by the committees. This is consistent with the general trend described in Section 4.1.

Overall, these results confirm a terminological dichotomy between: (1) terms whose literal translations either correspond to the denominations of judicial bodies of a similar nature in Spanish-speaking legal systems or are transparent and generic enough to facilitate conceptual identification and avert misunderstandings; and (2) terms that designate concepts of high legal singularity and no clear correspondence in the target legal systems. While the first group records high levels of intertextual consistency, STs in the second group tend to be translated in a rather inconsistent manner. 


\section{Concluding remarks}

The study reveals that the majority of selected national court names, 25 out of 30, are translated in various ways in documents produced in the UN monitoring procedures of human rights treaty compliance. Nevertheless, the translations of 13 STs are either fully consistent or hit marginal InterVaR and IntraVaR values. In other words, despite the prevalence of translation variability, in almost half of the cases the objective of terminological consistency in the target language is (nearly) attained. An in-depth examination of the results supports additional conclusions on the variables of the analysis.

Neither ST frequency nor the source language seem to have an impact on consistency levels. The frequency quintile comparison revealed an even distribution of STs per variation brackets, whereas STs of similar recurrence levels registered significant differences in variability. While more French STs fall into high-variation brackets, they also outweigh STs from English-speaking legal systems in low- or no-variation brackets.

Rather than frequency of use or translation directionality, the most determining factor in translation variability according to our data is the level of intersystemic incongruity or asymmetry associated with the culture-bound nature of each court name. The findings point to a terminological dichotomy in this respect. On the one hand, the assessment reveals extremely low levels of translation variation in the case of terms whose literal translations correspond to the denominations of judicial bodies of a similar nature in Spanish-speaking legal systems or are otherwise transparent or easy to recognise by the target audience. On the other hand, when terms designate courts without clear correspondence in the target legal systems, we observe higher levels of inconsistency. These patterns confirm that translation variability levels for national court names are conditioned by the degree of legal asymmetry of the source term. Last but not least, the study unveils a potential multiplier effect of source text length on the intratextual variation levels. This can be related to the common practice of assigning larger documents to multiple translators and the risk of insufficient terminological harmonisation due to time constraints. This factor seems to contribute to the IntraVaR results for both national reports and, to a lesser extent, replies to lists of issues. Presumably lower levels of quality control may also help to explain a higher IntraVaR for replies to lists of issues, especially as compared to individual complaint documents.

Our conclusions call for the examination of other aspects of translation process in order to better understand the trends elicited by this study, including the use of terminological resources, the connection between translation consistency and adequacy (the other key quality dimension addressed in the LETRINT project) and the potential impact of other procedural variables on all indicators 
over time (e.g., translator profiles or level of revision of different document types). As the study sheds light on a very specific segment of the UN's translation output, it should not be interpreted as a generalisation about translation practices at this organisation as a whole, but as a contribution to better understanding patterns of legal terminological decisions in international institutional settings.

\section{Acknowledgements}

This research is part of the project 'Legal Translation in International Institutional Settings: Scope, Strategies and Quality Markers' (https://transius.unige.ch/letrint/), which is conducted with the support of the Swiss National Science Foundation through a Consolidator Grant.

\section{References}

Biel, Łucja. 2014. Lost in the Eurofog. The Textual Fit of Translated Law. Frankfurt am Main: Peter Lang. https://doi.org/10.3726/978-3-653-03986-3

Cao, Deborah, and Xingmin Zhao. 2008. "Translation at the United Nations as Specialized Translation". The Journal of Specialised Translation, no. 9: 39-54.

Egan, Suzanne. 2013. "Strengthening the United Nations Human Rights Treaty Body System". Human Rights Law Review 13(2): 209-243. https://doi.org/10.1093/hrlr/ngtoo8

Galdia, Marcus. 2017. Lectures on Legal Linguistics. Bern: Peter Lang. https://doi.org/10.3726/b11443

García, Ramón. 2010. “El español, lengua de traducción en el sistema de las Naciones Unidas y en el de la Comunidad Europea". In Actas del IV congreso "El español, lengua de traducción”, ed. by Luis González and Pollux Hernúñez, 395-404. Madrid: ESLETRA.

McMahon, Edward. 2009. "Assessing the UPR Mechanism of the United Nations Human Rights Council”. African Yearbook of International Law no. 17: 355-377.

Millet, Muriel. 2013. "Legal Translation at INTERPOL”. In Legal Translation in Context. Professional Issues and Prospects, ed. by Anabel Borja Albi and Fernando Prieto Ramos, 243-262. Bern: Peter Lang.

Nóbrega, María. 2006. "La traducción en las Naciones Unidas: La Torre de Babel a orillas del East River". In Actas del IV congreso "El español, lengua de traducción”, ed. by Luis González and Pollux Hernúñez, 135-142. Madrid: ESLETRA.

Nóbrega, María. 2010. "Presencia del español en las organizaciones internacionales: Las Naciones Unidas". Puntoycoma no. 117: 24-27.

Peñaranda López, Antonio. 2015. Proceso penal comparado (España, Francia, Inglaterra, Estados Unidos, Rusia). Second edition. Granada: Editorial Comares.

Pérez-Barreiro Nolla, Fernando. 2005. “Treinta y cinco años de traducción en organizaciones internacionales. Brevísimas reflexiones personales”. In La traducción y la interpretación en las relaciones jurídicas internacionales, ed. by Esther Monzó Nebot and Anabel Borja Albi, 225-229. Castellón de la Plana: Universitat Jaume I. 
Peruzzo, Katia. 2019. "When international case-law meets national law. A corpus-based study on Italian system-bound loan words in ECtHR judgments”. Translation Spaces 8(1): 12-38. https://doi.org/10.1075/ts.00011.per

Prieto Ramos, Fernando. 2013. “QQué estrategias para qué traducción jurídica?: Por una metodología integral para la práctica professional”. In Translating the Law. Theoretical and Methodological Issues. Traducir el Derecho. Cuestiones teóricas y metodológicas, ed. by Icíar Alonso Araguás, Jesús Baigorri Jalón, and Helen J.L. Campbell, 87-105. Granada: Comares.

Prieto Ramos, Fernando. 2014a. "International and Supranational Law in Translation: From Multilingual Lawmaking to Adjudication”. The Translator 20(3): 313-331. https://doi.org/10.1080/13556509.2014.904080

Prieto Ramos, Fernando. 2014b. "Parameters for Problem-Solving in Legal Translation: Implications for Legal Lexicography and Institutional Terminology Management”. In The Ashgate Handbook of Legal Translation, ed. by Le Cheng, King Kui Sin, and Anne Wagner, 121-134. Farnham and Burlington: Ashgate.

Prieto Ramos, Fernando. 2020. "Translation at International Organizations: The Legal and Linguistic Hierarchies of Multilingualism". In The Oxford Handbook of Translation and Social Practices, ed. by Meng Ji and Sara Laviosa. New York: Oxford University Press. https://doi.org/10.1093/oxfordhb/9780190067205.013.13

Prieto Ramos, Fernando, Giorgina Cerutti, and Diego Guzmán. 2019. "Building Representative Multi-Genre Corpora for Legal and Institutional Translation Research: The LETRINT Approach to Text Categorization and Stratified Sampling”. Translation Spaces 8(1): 93-116. https://doi.org/10.1075/ts.00014.pri

Prieto Ramos, Fernando, and Diego Guzmán. 2018. “Terminological Consistency and Adequacy Levels in Institutional Translation: A Mixed-Method Comparative Study". In Institutional Translation for International Governance. Enhancing Quality in Multilingual Legal Communication, ed. by Fernando Prieto Ramos, 81-101. London: Bloomsbury.

Prieto Ramos, Fernando, and Diego Guzmán. 2021. "Examining Institutional Translation through a Legal Lens: A Comparative Analysis of Multilingual Text Production at International Organizations". Target. International Journal of Translation Studies. https://doi.org/10.1075/target.21003.pri

Rodley, Nigel S. 2013. "The Role and Impact of Treaty Bodies". In The Oxford Handbook of International Human Rights Law, ed. by Dinah Shelton, 621-648. Oxford: Oxford University Press. https://doi.org/10.1093/law/9780199640133.003.0027

Sáenz Sagaseta de Ilúrdoz, Miguel. 1999. “La traducción de textos jurídicos internacionales”. In Traducir para la justicia, ed. by Manuel C. Feria García, 3-15. Granada: Comares.

Šarčević, Susan. 1997. New Approach to Legal Translation. The Hague: Kluwer Law International.

Schmidt, Markus G. 2009. "Follow-up Activities by UN Human Rights Treaty Bodies and Special Procedures Mechanisms of the Human Rights Council - Recent Developments". In International Human Rights Monitoring Mechanisms, ed. by Gudmundur Alfredsson, Jonas Grimheden, Bertrand G. Ramcharan, and Alfred De Zayas, 25-34. Leiden: Martinus Nijhoff Publishers. https://doi.org/10.1163/ej.9789004162365.i-728.28 Vandenhole, Wouter. 2004. The Procedures Before the UN Human Rights Treaty Bodies. Divergence or Convergence? Antwerp: Intersentia. 
Zhao, Xingmin, and Deborah Cao. 2013. "Legal Translation at the United Nations". In Legal Translation in Context. Professional Issues and Prospects, ed. by Anabel Borja Albi and Fernando Prieto Ramos, 203-220. Bern: Peter Lang.

\section{Address for correspondence}

\section{Diego Guzmán}

Centre for Legal and Institutional Translation Studies (Transius)

Faculty of Translation and Interpreting

University of Geneva

40, boulevard du Pont-d'Arve

$\mathrm{CH}-1211$ Genève 4

Switzerland

Diego.Guzman@unige.ch

\section{Co-author information}

Fernando Prieto Ramos

Centre for Legal and Institutional Translation Studies (Transius)

Faculty of Translation and Interpreting

University of Geneva

Fernando.Prieto@unige.ch

\section{Publication history}

Date received: 5 September 2020

Date accepted: 30 December 2020

Published online: 2 July 2021 